\title{
A Methodology for Future Scenario Planning
}

\author{
Saskia Sardesai, Markus Stute, and Josef Kamphues
}

\begin{abstract}
The future is influenced by various possible developments and is hence difficult to predict. Still, each company or institution bases its vision and strategic progress on certain assumptions for the future. In order to prepare for various developments of the future, it is reasonable to consider different possible scenarios while building a future vision. Thus, this chapter focuses on the methodological approach for the generation of future scenarios showing what the surroundings for supply chains might be like in a time horizon until 2030. This integrates various political, economic, social, technological, legal and environmental influences and changes. The methodological framework required for generating scenarios is set by a combination of quantitative and qualitative scenario planning methodologies. Close coordination and collaboration between production and logistics guides the underlying scenario design to focus the context on supply chains. While considering trends described in Kalaitzi et al. 2020, this approach results in a set of macro scenarios, each describing a possible future development until 2030. The macro scenarios range from scenarios with progressive developments to regressing or stagnating evolutions.
\end{abstract}

Keywords Scenario planning $\cdot$ Trends $\cdot$ Supply chain management $\cdot$ Prediction

\section{Introduction to Scenario Planning}

Scenario planning is a proven approach to coping with uncertainties in today's rapidly changing world (DHL 2012). Since the 1950's, scenario planning has been used to help make public policy decisions-beginning with war game analyses at the Rand Corporation (Wilkinson and Eidinow 2008). Interest in the method has grown at the intersections of academia, the public and private sectors and policymaking.

Scenario planning forms a basis for learning through strategic conversation and it helps to build a consensus in terms of considering the probability of certain future

\footnotetext{
S. Sardesai $(\bowtie) \cdot$ M. Stute $\cdot$ J. Kamphues

Fraunhofer Institute for Material Flow and Logistics, Joseph-von-Fraunhofer-Str. 2-4, 44137

Dortmund, Germany

e-mail: saskia.sardesai@iml.fraunhofer.de

(C) The Author(s) 2021

R. Fornasiero et al. (eds.), Next Generation Supply Chains, Lecture Notes in Management and Industrial Engineering, https://doi.org/10.1007/978-3-030-63505-3_2
} 
developments (so called 'projections') (Wilkinson and Eidinow 2008). The methodology supports the creation of different scenarios in order to be prepared for various possible future developments. It results in a set of several scenarios in which each set claims a different probability level. Compared to the fixed results achieved by traditional methods, this methodology provides a set of possible ways forward while retaining uncertainty (Wilkinson and Eidinow 2008). Accordingly, it differs from other future research approaches, such as predictions and forecasts, as it integrates different combinations of future states, so called scenarios.

The methodology is specifically useful in the context of future statements with different levels of uncertainty. It provides a holistic and schematic overview to describe a possible future condition. Each resulting scenario details causal relationships between a set of projections of future developments. It describes a version of the future which originates from the current state of developments (Meinert 2014). The generated scenarios help organisations to react to changes, make decisions, be prepared for and adapt quickly to upcoming environmental changes and thus improve the quality of strategic thinking (DHL 2012). The methodology also allows public authorities to evaluate future developments e.g. to prepare for stocks of mouth and nose masks in case of pandemic events. Thus, the methodology helps organisations and public authorities to prepare for possibilities and to ensure innovative and flexible development (Amer et al. 2013).

Boerjeson et al. distinguish between three main scenario categories, namely predictive, explorative and normative. Predictive scenarios respond to the question "What will happen?"; explorative scenarios consider the question "What can happen?"; and the normative scenarios focus on "How can a specific goal be achieved?". In addition, they can be classified according to the topic (i.e. global scenarios or problem specific) and its level of aggregation (e.g. macro or micro) (Amer et al. 2013).

The literature for the development of scenarios is diverse and wide-ranging and there are many definitions, typologies and methodologies (Enserink et al. 2013) with different utilities, strengths and weaknesses (Amer et al. 2013). In the underlying topic, the scenarios are intended to serve as an aid to policy planning within the logistics sector. In this case, the explorative long-term horizon within the definition of Boerjeson et al. is considered, aiming at the question: "What can happen?". According to Boerjeson et al. this category is further differentiated into external and strategic scenarios. While strategic scenarios focus on internal factors, external scenarios address the development of external factors that cannot be influenced by an actor, e.g. a company or a political unit (Boerjeson et al. 2006).

\section{Methodological Approach for Scenario Planning}

With regard to the generation of scenarios, the approach used in this work is closely linked to a methodology proposed by Gausemeier and Plass (2014). The approach belongs to the category of quantitative approaches and uses a cross-impact and 
consistency matrix to develop a set of scenarios. Being in line with the rational, objectivist school, a cross-impact analysis of future projections serves to identify correlations and causal impacts (Amer et al. 2013). It is complemented by qualitative methods to enhance the plausibility of the scenarios. The resulting scenarios represent macro-scenarios outlining the future industrial surroundings based on a trend analysis according to PESTLE dimensions (political, economic, social, technological, legal and environmental influences). The methodology applied here has the strong advantage of allowing several ways for the development of the future and of enabling the inclusion of complex future developments that result from different trends and perspectives. While integrating the complex surroundings, the methodology uses a powerful methodology to compress various future projections to select a few scenarios for a more detailed analysis (Gausemeier et al. 1995). The approach is separated into five different steps as shown in Fig. 1, where the approach as suggested by Gausemeier is compared to the applied approach.

The first step of the Gausemeier approach comprises a definition of the envisaged scope and timeline as well as the underlying decision-field-analysis. Step 2 conducts a scenario-field-analysis that identifies and describes major influencing trends within the decision-field. Step 3 clusters the trends to state future projections. Those projections are integrated into a cross-impact matrix to form future projection bundles and thus preliminary scenarios. Step 4 evaluates the consistency of the

\begin{tabular}{|c|c|c|c|}
\hline \multicolumn{2}{|c|}{ Gausemeier-Approach } & \multicolumn{2}{|c|}{ Applied Approach } \\
\hline $\begin{array}{l}\text { Step 1: } \\
\text { Scenario- } \\
\text { Preparation }\end{array}$ & $\begin{array}{l}\text { - Project description } \\
\text { - Decision-Field-Analysis }\end{array}$ & & $\begin{array}{l}\text { - PESTLE Approach } \\
\text { - Timeline until } 2030\end{array}$ \\
\hline \multicolumn{4}{|c|}{ 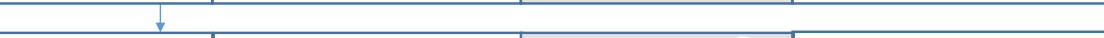 } \\
\hline $\begin{array}{l}\text { Step 2: } \\
\text { Scenario-Field- } \\
\text { Analysis }\end{array}$ & $\begin{array}{l}\text { - Identification of } \\
\text { - influence areas } \\
\text { - influencing factors } \\
\text { - key factors }\end{array}$ & & $\begin{array}{l}\text { Megatrend-Analysis \& Trend- } \\
\text { Analysis according to PESTLE } \\
\text { Dimensions }\end{array}$ \\
\hline \multicolumn{4}{|c|}{$\frac{1}{1}$} \\
\hline $\begin{array}{l}\text { Step 3: } \\
\text { Scenario- } \\
\text { Projection }\end{array}$ & $\begin{array}{l}\text { Preparation of the } \\
\text { key factors } \\
\text { Identification of future } \\
\text { projections }\end{array}$ & 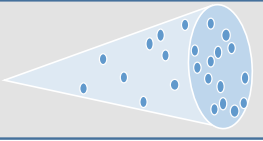 & $\begin{array}{l}\text { " Projections based on } \\
\text { megatrends } \\
\text { " Impact of a projection on the } \\
\text { Supply Chain } \\
\text { " Evaluation of influences }\end{array}$ \\
\hline \multicolumn{4}{|r|}{ ten on } \\
\hline $\begin{array}{l}\text { Step 4: } \\
\text { Scenario- } \\
\text { Building }\end{array}$ & $\begin{array}{l}\text { - Projection bundles } \\
\text { - Prescenario-building } \\
\text { - Future mapping } \\
\text { - Scenario description }\end{array}$ & $\Longleftarrow$ & $\begin{array}{l}\text { - Clustering of projections with } \\
\text { cross-impact matrix } \\
\text { - Scenario Narratives for } \\
\text { Macro-Scenarios }\end{array}$ \\
\hline \\
\hline $\begin{array}{l}\text { Step 5: } \\
\text { Scenario- } \\
\text { Transfer }\end{array}$ & $\begin{array}{l}\text { - Consequences } \\
\text { - Opportunities / Threats } \\
\text { - Strength/Weaknesses } \\
\text { - Strategies }\end{array}$ & 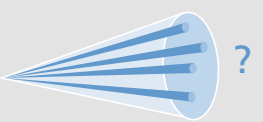 & $\begin{array}{l}\text { - Discussion of Implications } \\
\text { - Discussion of Strategies }\end{array}$ \\
\hline
\end{tabular}

Fig. 1 Application of the Gausemeier approach (own representation following Gausemeier et al. 1995) 
scenarios via cross-impact analysis resulting in a set of final scenarios. As the crossimpact evaluation is a pure mathematical approach, a qualitative approach enhances the methodology with a validation of the plausibility of each scenario. Accordingly, experts are invited to evaluate the probability of occurrence of each scenario and its impact on the supply chain. Finally, a storyline for each macro scenario details the scenario settings and conveys the differences of each scenario to the decision-making units. While reflecting on the impact of each scenario, conclusions have to be drawn on how to prepare for, or even influence, different alternatives. Step 5 is dedicated to scenario transfer that aims at developing appropriate strategies for each scenario.

As the first two steps (scenario preparation and field analysis) are described in Kalaitzi et al. (2020), the following sections detail step 3 (scenario projection) and parts of step 4 (scenario building). Sardesai et al. (2020) refines the scenario narratives and impact of each scenario on supply chains. Barros et al. (2020) provides the methodological approach for scenario transfer and supply chain strategies for each macro-scenario.

\section{Scenario-Projection-Conception of Future Projections}

The creation of future projections relies on previously identified trends and megatrends. The six PESTLE dimensions set the framework and form subsections, each incorporating several so-called 'descriptors' (Gausemeier and Plass 2014). Descriptors express a neutral form of future topics and are characterised by diverging future projections. Future projections express a certain future state of a descriptor and describe possible circumstances that companies and societies might face. Most commonly, a descriptor comprises a positive, negative and neutral future projection.

The development of future projections for the descriptors is a decisive step in the scenario planning as they create the structural components for the upcoming scenarios. The significance and quality of the scenarios depend on it, and thus ultimately the success of the entire scenario project, too. Generally, future projections have to contain plausible future states and it is necessary to consider extreme but possible developments. At the same time, it is essential that each projection remains reasonable and conceivable, in the sense that a projection can be futuristic but needs to rely on valid arguments or requires justification by means of statistical developments (Gausemeier and Plass 2014). Careful attention has to be paid to the distinctness of the projections to ensure that the subsequent consistency check leads to reasonable combinations of projections and consistent scenarios. Hence, the projections have to fulfil the following criteria:

- Plausibility - a projection needs to be plausible to the scenario team.

- Dissimilarity-all projections have to be distinct from each other.

- Completeness - a set of projections within a descriptor has to provide a comprehensive set of possible developments.

- Relevance_-each projection requires a check regarding its future relevance. 
- Information content- - each projection needs to add further value to the set of projections within a descriptor.

Table 1-Table 6 list the different descriptors and future projections that result from the underlying field analysis (see Kalaitzi et al. 2020; Daus et al. 2018). The projections are separated according to the six PESTLE dimensions.

Table 1 Overview of the resulting projections for the political dimension

\begin{tabular}{|c|c|c|}
\hline \multicolumn{3}{|c|}{ Political dimension } \\
\hline \multirow[t]{3}{*}{ Political setting } & Political concord in Europe & $\begin{array}{l}\text { We experience a politically stable } \\
\text { environment in Europe. States at the } \\
\text { border region and trade partners are } \\
\text { living in peace (Stiftung 2018) }\end{array}$ \\
\hline & Constant development in Europe & $\begin{array}{l}\text { The number of terrorist attacks is slowly } \\
\text { decreasing due to stronger security } \\
\text { enforcements (Stiftung 2018; } \\
\text { EUROPOL 2017) }\end{array}$ \\
\hline & Governmental collapse in Europe & $\begin{array}{l}\text { Social unrest and conflicts characterize } \\
\text { everyday life throughout European } \\
\text { countries. Frequent strikes occur and } \\
\text { terrorist attacks hinder economic growth } \\
\text { (Stiftung 2017b) }\end{array}$ \\
\hline \multirow[t]{2}{*}{ Trade policies } & Protectionism & $\begin{array}{l}\text { We experience a policy of protecting } \\
\text { domestic industries against foreign } \\
\text { competition entailing a rise in trade } \\
\text { policies such as tariffs, import quotas (de } \\
\text { Kluyver 2010) }\end{array}$ \\
\hline & Free trade & $\begin{array}{l}\text { We experience a policy of open trade, not } \\
\text { discriminating against imports from and } \\
\text { exports to foreign competitors. Countries } \\
\text { are interested in making trade as easy as } \\
\text { possible (World Economic Forum 2016b) }\end{array}$ \\
\hline \multirow[t]{3}{*}{ Confederation } & Contended Union & $\begin{array}{l}\text { Asian, Latin American and other } \\
\text { countries form state unions. EU Member } \\
\text { States act as a single political, economic } \\
\text { area promoting free movement of goods, } \\
\text { services, capital and people (World } \\
\text { Economic Forum 2016b) }\end{array}$ \\
\hline & Unstable confederations & $\begin{array}{l}\text { Some countries push for change and } \\
\text { express their discontent with the } \\
\text { confederation. Free movement and trade } \\
\text { agreements remain (Stokes 2016) }\end{array}$ \\
\hline & Fragmentation & $\begin{array}{l}\text { The EU is going into crisis and several } \\
\text { countries are leaving the confederation } \\
\text { (Stiftung 2017a) }\end{array}$ \\
\hline
\end{tabular}


Table 2 Overview of the resulting projections for the economic dimension

\begin{tabular}{|c|c|c|}
\hline \multicolumn{3}{|l|}{ Economic dimension } \\
\hline \multirow[t]{2}{*}{ Global trade shift } & The pendulum shifts & $\begin{array}{l}\text { Global market demand and trade } \\
\text { shifts specifically to Asia. It is } \\
\text { projected that new emerging } \\
\text { economies such as Mexico and } \\
\text { Indonesia will be larger than the } \\
\text { UK and France by } 2030 \text { (WTO } \\
\text { 2017) }\end{array}$ \\
\hline & Steady Titans US and Europe & $\begin{array}{l}\text { US and Europe manage to keep } \\
\text { export trading volume high, and } \\
\text { heavily invest in education and } \\
\text { new technologies (PwC-Price } \\
\text { Waterhouse Coopers 2015) }\end{array}$ \\
\hline \multirow[t]{2}{*}{ Global corporate structures } & Think global, act local & $\begin{array}{l}\text { An increase in wages in } \\
\text { previously low-wage countries, } \\
\text { and cost of shipping and custom } \\
\text { fees, make local production } \\
\text { attractive again. Companies } \\
\text { follow market demand and } \\
\text { primarily offer and source local } \\
\text { products (Menon 2014) }\end{array}$ \\
\hline & Rise of born-global firms & $\begin{array}{l}\text { Digitalisation helps SMEs and } \\
\text { start-ups to participate on a } \\
\text { global level. Born-global firms } \\
\text { are innovative in all areas of } \\
\text { value creation, both } \\
\text { technological and } \\
\text { non-technological } \\
\text { (Weerawardena et al. 2007) }\end{array}$ \\
\hline \multirow[t]{2}{*}{ Digital economy } & Pure traditional economy & $\begin{array}{l}\text { People object to digitalisation } \\
\text { and accept limited online } \\
\text { functionality due to privacy. } \\
\text { Traditional physical goods such } \\
\text { as hardcopies of books are } \\
\text { preferred (Brynjolfsson and } \\
\text { Kahin 2000) }\end{array}$ \\
\hline & Traditional economy persists & $\begin{array}{l}\text { The traditional way is upheld } \\
\text { due to fear of data misuse and } \\
\text { legal and political concerns limit } \\
\text { development. Even though } \\
\text { traditional business needs to } \\
\text { cooperate with online platforms } \\
\text { (such as for food delivery } \\
\text { services or fashion), customers } \\
\text { continue to e.g. eat and shop the } \\
\text { conventional way (Laudon and } \\
\text { Traver 2014) }\end{array}$ \\
\hline
\end{tabular}


Table 2 (continued)

\begin{tabular}{|c|c|c|}
\hline \multicolumn{3}{|l|}{ Economic dimension } \\
\hline & Platform economy & $\begin{array}{l}\text { Expanding digital economy } \\
\text { B2B by developing more } \\
\text { collaborative platforms enabling } \\
\text { an easy share and utilisation of } \\
\text { resources (hubs, terminals, etc.) } \\
\text { (PwC-Price Waterhouse } \\
\text { Coopers 2017b) }\end{array}$ \\
\hline \multirow[t]{3}{*}{ Financial innovations } & Bank and Fintech collaboration & $\begin{array}{l}\text { The rise of Fintech companies } \\
\text { transforms bank institutions and } \\
\text { other sectors. Start-up } \\
\text { companies compete with } \\
\text { traditional banking by focusing } \\
\text { on digital processes and } \\
\text { innovation, thus enabling better } \\
\text { customer interactions } \\
\text { (PwC-Price Waterhouse } \\
\text { Coopers 2017a) }\end{array}$ \\
\hline & A world without banks & $\begin{array}{l}\text { Smart ledgering enables a new } \\
\text { kind of trading. It is possible for } \\
\text { each individual to create their } \\
\text { own virtual currency. } \\
\text { Transactions are secured via } \\
\text { new technologies, e.g. } \\
\text { blockchain. Using secure web } \\
\text { services, devices submit } \\
\text { financial transactions } \\
\text { autonomously (Karathodorou; } \\
\text { Fintechnews Singapore 2016) }\end{array}$ \\
\hline & Big 5 are the banks of the future & $\begin{array}{l}\text { Trusted third party services } \\
\text { develop their own digital } \\
\text { currencies, taking over the } \\
\text { "traditional" currencies. E.g., } \\
\text { the big five IT companies offer } \\
\text { their own currencies to facilitate } \\
\text { seamless payment between both } \\
\text { people and devices (Shah et al. } \\
\text { 2016) }\end{array}$ \\
\hline
\end{tabular}


Table 3 Overview of the resulting projections for the social dimension

\begin{tabular}{|c|c|c|}
\hline \multicolumn{3}{|l|}{ Social dimension } \\
\hline \multirow[t]{2}{*}{ Demographic change } & $\begin{array}{l}\text { Ageing population and } \\
\text { acceleration of disparities }\end{array}$ & $\begin{array}{l}\text { Due to longer and healthier } \\
\text { lives in developed countries, a } \\
\text { significant increase in older } \\
\text { populations can be assumed } \\
\text { (Krys and Fuest 2017) }\end{array}$ \\
\hline & $\begin{array}{l}\text { Awareness of inequalities and } \\
\text { wealth redistribution }\end{array}$ & $\begin{array}{l}\text { New forms of solidarity, social } \\
\text { engagement and civil } \\
\text { participation develop within } \\
\text { society supporting fast } \\
\text { integration of migrating young } \\
\text { people (Krys and Fuest 2017) }\end{array}$ \\
\hline \multirow[t]{2}{*}{ Urban living } & Smart regions & $\begin{array}{l}\text { Some people leave the cities to } \\
\text { live in the countryside. While } \\
\text { people continue to work in } \\
\text { cities, they look forward to a } \\
\text { break in the countryside (Zelt } \\
\text { et al. 2017) }\end{array}$ \\
\hline & Smart cities & $\begin{array}{l}\text { Smart cities with free Wi-Fi in } \\
\text { all public spaces, where } \\
\text { children learn how to program } \\
\text { apps in elementary school, } \\
\text { goods are delivered to homes } \\
\text { within hours, and e.g. street } \\
\text { lighting is provided on demand } \\
\text { (Zelt et al. 2017) }\end{array}$ \\
\hline \multirow[t]{3}{*}{ Consumption patterns } & Much and cheap & $\begin{array}{l}\text { We experience a throwaway } \\
\text { society in which people focus } \\
\text { on convenient and mass } \\
\text { products (Kharas 2017) }\end{array}$ \\
\hline & Consumption awareness & $\begin{array}{l}\text { Customers receive detailed } \\
\text { information about products they } \\
\text { buy. An ecological mind-set } \\
\text { determines consumption and } \\
\text { products within other sectors } \\
\text { like transportation (Kharas } \\
\text { 2017; Eurostat 2016) }\end{array}$ \\
\hline & DIY Society & $\begin{array}{l}\text { Motivated by increased } \\
\text { consumption awareness, a } \\
\text { perceived lack of quality from } \\
\text { available offerings and the need } \\
\text { for customisation, people } \\
\text { become strongly involved in the } \\
\text { production process (Wolf and } \\
\text { McQuitty 2011) }\end{array}$ \\
\hline
\end{tabular}


Table 3 (continued)

\begin{tabular}{|c|c|c|}
\hline \multicolumn{3}{|l|}{ Social dimension } \\
\hline & Individualised consumption & $\begin{array}{l}\text { A transition towards small } \\
\text { scaled households affects the } \\
\text { quantity sizes demanded and } \\
\text { the way products are requested, } \\
\text { purchased and consumed in } \\
\text { each household (Agriculture } \\
\text { and Agri-Food Canada 2010) }\end{array}$ \\
\hline \multirow[t]{2}{*}{ Customer orientation } & $\begin{array}{l}\text { Individualism—focus on } \\
\text { variety }\end{array}$ & $\begin{array}{l}\text { Personalised purchases are } \\
\text { offered in categories like } \\
\text { holidays, clothing and furniture. } \\
\text { Companies postpone their } \\
\text { production until the latest point } \\
\text { possible to allow individual } \\
\text { customisation (Deloitte 2015) }\end{array}$ \\
\hline & $\begin{array}{l}\text { Collectivism-focus on the } \\
\text { crowd }\end{array}$ & $\begin{array}{l}\text { Social networks strongly } \\
\text { influence buying behaviour and } \\
\text { hence, companies have to adapt } \\
\text { quickly on a large scale (Frank } \\
\text { et al. 2015) }\end{array}$ \\
\hline \multirow[t]{2}{*}{ Knowledge-based economy } & $\begin{array}{l}\text { Investments equalize the } \\
\text { labour market }\end{array}$ & $\begin{array}{l}\text { The investment in new } \\
\text { production structures and new } \\
\text { facilities partly equalizes low } \\
\text { skilled job opportunities lost } \\
\text { due to autonomisation (Lorenz } \\
\text { et al. 2016) }\end{array}$ \\
\hline & $\begin{array}{l}\text { Rapid changes cause } \\
\text { unemployment }\end{array}$ & $\begin{array}{l}\text { Several industry sectors are } \\
\text { affected by autonomisation, } \\
\text { which leads to a high overall } \\
\text { rate of unemployment, a loss of } \\
\text { seven million jobs in } \\
\text { transportation alone is predicted } \\
\text { (Lorenz et al. 2016) }\end{array}$ \\
\hline
\end{tabular}


Table 4 Overview of the resulting projections for the technological dimension

\begin{tabular}{|c|c|c|}
\hline \multicolumn{3}{|l|}{ Technological dimension } \\
\hline \multirow[t]{3}{*}{ Digital transformation } & $\begin{array}{l}\text { Rapid advancement of } \\
\text { digitalisation }\end{array}$ & $\begin{array}{l}\text { The overall technological } \\
\text { development evolves fast in an } \\
\text { open manner and enables small } \\
\text { and multinational companies to } \\
\text { profit from products and } \\
\text { services that are increasingly } \\
\text { personalised, data-intensive and } \\
\text { context-aware (World } \\
\text { Economic Forum 2016a) }\end{array}$ \\
\hline & $\begin{array}{l}\text { Obstacles restrain digital } \\
\text { transformation }\end{array}$ & $\begin{array}{l}\text { Performance improvements } \\
\text { through digital transformation } \\
\text { seem obvious, but can seldom } \\
\text { be verified and lack proof of } \\
\text { evidence (Bouee and Schaible } \\
\text { 2015) }\end{array}$ \\
\hline & Digital stagnation & $\begin{array}{l}\text { Only a few companies attempt } \\
\text { to promote digital } \\
\text { transformation further but are } \\
\text { struggling with a lack of } \\
\text { compliant regulations and } \\
\text { political support (Bingley et al. } \\
2016 \text { ) }\end{array}$ \\
\hline \multirow[t]{2}{*}{ Autonomous systems } & $\begin{array}{l}\text { Dynamic development of } \\
\text { autonomous technologies }\end{array}$ & $\begin{array}{l}\text { Cyber-physical systems enable } \\
\text { efficient communication and } \\
\text { control by transferring and } \\
\text { exchanging data in real time. } \\
\text { An increased exploitation of } \\
\text { these technologies leads to a } \\
\text { highly automated, autonomous } \\
\text { environment (Bingley et al. } \\
\text { 2016) }\end{array}$ \\
\hline & $\begin{array}{l}\text { Innate reluctance to accept } \\
\text { autonomous technologies }\end{array}$ & $\begin{array}{l}\text { Since an autonomous } \\
\text { technology requires suites of } \\
\text { expensive sensors, the average } \\
\text { cost of this technology remains } \\
\text { high. In addition, regulations } \\
\text { prevent the full exploitation of } \\
\text { their potentials (Omohundro } \\
\text { 2014) }\end{array}$ \\
\hline $\begin{array}{l}\text { Alternative energy generation, } \\
\text { storage and usage }\end{array}$ & $\begin{array}{l}\text { Established electrification } \\
\text { technologies and green } \\
\text { systems }\end{array}$ & $\begin{array}{l}\text { New power grid solutions and } \\
\text { grid transformations overcome } \\
\text { technological limitations. This } \\
\text { enables a smart grid } \\
\text { environment with distributed } \\
\text { energy generation and powerful } \\
\text { storage systems (Howell et al. } \\
\text { 2017) }\end{array}$ \\
\hline
\end{tabular}


Table 4 (continued)

\begin{tabular}{|c|c|c|}
\hline \multicolumn{3}{|l|}{ Technological dimension } \\
\hline & $\begin{array}{l}\text { Ongoing electrification and } \\
\text { alternative energy } \\
\text { endeavours }\end{array}$ & $\begin{array}{l}\text { Green systems used for power } \\
\text { generation, energy storage and } \\
\text { transportation, such as } \\
\text { hydrogen power cells and } \\
\text { biomass, are gradually applied } \\
\text { in industrial and social sectors } \\
\text { (McKinsey 2010) }\end{array}$ \\
\hline \multirow[t]{2}{*}{$\begin{array}{l}\text { Decentralised connection of } \\
\text { information and physical } \\
\text { devices }\end{array}$} & Dominance of global players & $\begin{array}{l}\text { Only global players have } \\
\text { significant resources, global } \\
\text { data sets and institutional } \\
\text { know-how to harness for their } \\
\text { digital transformation (DHL } \\
\text { Customer Solutions and } \\
\text { Innovation 2016) }\end{array}$ \\
\hline & $\begin{array}{l}\text { Start-ups and SMEs take up } \\
\text { business }\end{array}$ & $\begin{array}{l}\text { Many small and medium-sized } \\
\text { enterprises (SMEs) and } \\
\text { start-ups attack traditional } \\
\text { markets, due to the } \\
\text { democratisation of technology, } \\
\text { increased access to funds and a } \\
\text { rising entrepreneurial culture } \\
\text { (Coleman et al. 2016) }\end{array}$ \\
\hline \multirow[t]{2}{*}{$\begin{array}{l}\text { Disruptive production } \\
\text { technologies }\end{array}$} & $\begin{array}{l}\text { Continuous exploitation of } \\
\text { disruptive technologies }\end{array}$ & $\begin{array}{l}\text { Suppliers of disruptive } \\
\text { technologies experience } \\
\text { exponential growth rates. } \\
\text { Existing technologies are } \\
\text { improved and additional } \\
\text { solutions are developed in a } \\
\text { rapid and continuous manner } \\
\text { (Jiang et al. 2017) }\end{array}$ \\
\hline & $\begin{array}{l}\text { Coexistence of conventional } \\
\text { and disruptive technologies }\end{array}$ & $\begin{array}{l}\text { Conventional technologies and } \\
\text { disruptive technologies coexist } \\
\text { in industry. A widespread } \\
\text { implementation of disruptive } \\
\text { technologies is missing due to } \\
\text { high associated costs, lack of } \\
\text { expertise and uncertainty of } \\
\text { quality (Bingley et al. 2016) }\end{array}$ \\
\hline
\end{tabular}


Table 5 Overview of the resulting projections for the legal dimension

\begin{tabular}{|c|c|c|}
\hline \multicolumn{3}{|l|}{ Legal dimension } \\
\hline \multirow[t]{2}{*}{ Consumer Protection Laws } & $\begin{array}{l}\text { Promotion of laws and full } \\
\text { product transparency }\end{array}$ & $\begin{array}{l}\text { Safety and approval regulations } \\
\text { for new products are in place and } \\
\text { constantly monitored. For cross } \\
\text { border transactions, the required } \\
\text { general legislation has been } \\
\text { adopted and consumers' } \\
\text { personal data are strictly } \\
\text { protected in the EU (PwC-Price } \\
\text { Waterhouse Coopers 2011) }\end{array}$ \\
\hline & $\begin{array}{l}\text { Legislation is lagging behind } \\
\text { dynamic market development }\end{array}$ & $\begin{array}{l}\text { Arising trends (e.g. sharing } \\
\text { economy, digital market) lack } \\
\text { legislative clarity and are still } \\
\text { key priorities for regulations and } \\
\text { consumer protection laws in } \\
\text { Europe (Rhodes 2017) }\end{array}$ \\
\hline \multirow[t]{2}{*}{ Intellectual property laws } & $\begin{array}{l}\text { Full security for inventors and } \\
\text { data providers }\end{array}$ & $\begin{array}{l}\text { Secure peer-to-peer data } \\
\text { networks allow regulated data } \\
\text { transfer supported by politics, } \\
\text { businesses and research (Mittal } \\
\text { et al. 2017) }\end{array}$ \\
\hline & $\begin{array}{l}\text { Low confidentiality for data } \\
\text { and market participants }\end{array}$ & $\begin{array}{l}\text { Comprehensive data exchange } \\
\text { via conventional business } \\
\text { platforms, especially with } \\
\text { potential competitors, is a } \\
\text { challenge since core data and } \\
\text { business secrets are exposed and } \\
\text { liability regulations are missing } \\
\text { in case of infringement } \\
\text { (PwC-Price Waterhouse } \\
\text { Coopers 2016) }\end{array}$ \\
\hline \multirow[t]{2}{*}{$\begin{array}{l}\text { Social and environmental } \\
\text { regulations }\end{array}$} & $\begin{array}{l}\text { Comprehensive regulatory } \\
\text { framework }\end{array}$ & $\begin{array}{l}\text { Standards exists on how } \\
\text { frameworks and reports for } \\
\text { setting regulations are } \\
\text { communicated. New legislator } \\
\text { decisions facilitate business and } \\
\text { set decisive, easy to implement } \\
\text { regulations in terms of corporate } \\
\text { responsibility (CR) and } \\
\text { sustainability (Governance and } \\
\text { Accountability Institute 2016) }\end{array}$ \\
\hline & Heterogeneous regulations & $\begin{array}{l}\text { Standards and widely accepted } \\
\text { regulatory frameworks are } \\
\text { missing in Europe as well as } \\
\text { worldwide (Ceniga and } \\
\text { Sukalovaba 2015) }\end{array}$ \\
\hline
\end{tabular}


Table 6 Overview of the resulting projections for the environmental dimension

\begin{tabular}{|c|c|c|}
\hline \multicolumn{3}{|l|}{ Environmental dimension } \\
\hline \multirow[t]{2}{*}{ Climate impact } & Our environment is recovering & $\begin{array}{l}\text { Rapid improvements in energy } \\
\text { efficiency and a greater share of } \\
\text { zero- and low-carbon energy } \\
\text { supply reduce and maintain global } \\
\text { warming at an environmentally } \\
\text { acceptable rate (European } \\
\text { Commission 2016). The number } \\
\text { of natural disasters stabilises and } \\
\text { even declines slightly. Incidents of } \\
\text { pandemics or epidemics and } \\
\text { general infectious diseases appear } \\
\text { less frequently (WHO 2004) }\end{array}$ \\
\hline & Our environment on the brink & $\begin{array}{l}\text { Rising atmospheric } \mathrm{CO}_{2} \\
\text { concentration and rising } \\
\text { temperatures reach new peaks as } \\
\text { time passes. Crucial signs for } \\
\text { continued climate change } \\
\text { (Schwartz et al. 2014). The } \\
\text { frequency of pandemics and } \\
\text { epidemics increases along with } \\
\text { the deterioration of the } \\
\text { environment. Natural hazards like } \\
\text { floods and hurricanes become } \\
\text { very common and support the } \\
\text { spread of epidemics }\end{array}$ \\
\hline \multirow[t]{2}{*}{$\begin{array}{l}\text { Environmental resource } \\
\text { management }\end{array}$} & Countering resource depletion & $\begin{array}{l}\text { Improvements to the collection, } \\
\text { treatment and recycling of waste, } \\
\text { particularly of electronics and } \\
\text { plastics at end of life, contribute } \\
\text { to circular economy endeavours } \\
\text { (European Commission 2018) }\end{array}$ \\
\hline & $\begin{array}{l}\text { Rise in depletion of natural } \\
\text { resources }\end{array}$ & $\begin{array}{l}\text { Ever-increasing global population, } \\
\text { economic growth and demand for } \\
\text { resources from affluent consumers } \\
\text { contribute highly to severe } \\
\text { ongoing depletion of resources } \\
\text { (Krys and Fuest 2016) }\end{array}$ \\
\hline
\end{tabular}




\section{Scenario Building-Creation of Scenarios}

The major challenges in scenario building comprise, on the one hand, the evaluation of the credibility of different combinations of projections and, on the other hand, the aggregation of coherent combinations of projections to a scenario. To overcome these challenges, the scenario building technique within scenario planning contains powerful tools to identify contextual challenges and opportunities. The technique highlights the implications of possible future systems and projects consequences of choices or policy decisions (Amer et al. 2013).

The tools and methods of scenario building evaluate possible combinations of future projections. Each resulting set of future projections forms a scenario. This can result in a high number of different scenarios, some of them with a low credibility of interrelation. Such contradictions are referred to as inconsistencies (Gausemeier and Plass 2014). This implies that a scenario has a tendency to implausibility in cases of a high number of inconsistent future projections. It is therefore necessary to evaluate the consistency of each scenario as it acts as a decisive factor for its credibility.

There are several methodologies to evaluate the consistency of a scenario. The simple consistency analysis itself has certain constraints and practice has demonstrated that a simple consistency analysis does not sufficiently limit the spectrum of possibilities. To further restrict the spectrum of possibilities, Theodore Jay Gordon and Olaf Helmer developed a Cross-Impact Analysis (Gordon 1994), later extended as a Cross-Impact Balance Analysis (CIB). Similar to a consistency analysis, a CIB assesses the relationships between the factors in pairs. In contrast to the consistency analysis though, a CIB does not assess the concurrence of two future projections, but the direct effect that the occurrence of one future projection has on the other. A CIB therefore works with causal information (Weimer-Jehle 2009) and utilises qualitative insights of the individual relationship between the factors of the network thus constructing consistent images of its overall behaviour (ZIRIUS 2020). The scenario technique is one of the typical applications of CIB.

Depending on the method used, the impact assessment is either carried out along with an evaluation of probabilities, or, similar to consistency analysis, by qualitative assessments on an ordinal scale. Mathematical simulations or calculations support the evaluation process which has given cross-impact analysis the reputation of oversized mathematisation among qualitatively oriented scenario analysts. Still, the mathematical approach facilitates the implementation in a tool such as the CIB tool developed under the leadership of Dr. Weimer-Jehle at the University of Stuttgart. The tool is available on an open source basis, in order to benefit from the advantages of this methodology (see https://www.cross-impact.de/english/CIB_e.htm). 


\subsection{Evaluation of Impacts of Future Projections via the Cross-Impact Matrix}

The methodology of the Cross-Impact Matrix, as part of the CIB, is based on a matrix that plots the future projections, once in the ordinate and once in the abscissa. The evaluation of the impact between two future projections takes place in a group of experts who evaluate and assess the direct impact between two future projections. The group of experts should consist of people with a diversified background to ensure a broad view on the evaluation of the projections. As an example, the evaluation can consider the following scale:

$\mathbf{- 2}=$ strong impeding influence, i.e. future projection A1.1 has a strong inhibiting influence on the future projection A2.1. A common occurrence in a scenario has to be argued.

$\mathbf{- 1}=$ moderate impeding influence, i.e. future projection A1.1 has a moderate inhibiting influence on future projection A2.1.

$\mathbf{0}=$ neutral or independent influence, i.e. the respective future projection does not affect the other.

1 = moderate supporting influence, i.e. future projection A1.1 has a light supporting effect on future projection A2.1. Both future projections may well occur in a scenario.

$\mathbf{2}$ = strong supporting influence, i.e. the future projection A1.1 has a strong supporting effect on future projection A2.1. If future projection A1.1 occurs in a scenario, future A2.1 can also be expected to be in the same scenario.

In contrast to the consistency analysis, the CIB matrix must be filled in completely in order to be able to express the causality of the relationships (Weimer-Jehle 2006, 2008). An extract of the CIB matrix is shown in Fig. 2 along with the applied procedure.

It is recommended to invite several expert groups to evaluate the Cross-Impact Matrix in order to ensure objectivity. Resulting matrices can be consolidated by using a scaling up mechanism. This means that the target matrix consists of the sum of the individual judgement matrices. By comparing two matrices, this extends the range of judgement to -4 to 4 . Scaling-up has no influence on the later evaluation, but allows a differentiated evaluation.

\subsection{Development of Future Scenarios with the Cross-Impact Balance Analysis}

The CIB uses an inductive approach to form different sets of scenarios. The consistency analysis is the core of the CIB procedure. The method assesses the plausibility of the combined future projections within a scenario. Based on the output of the 


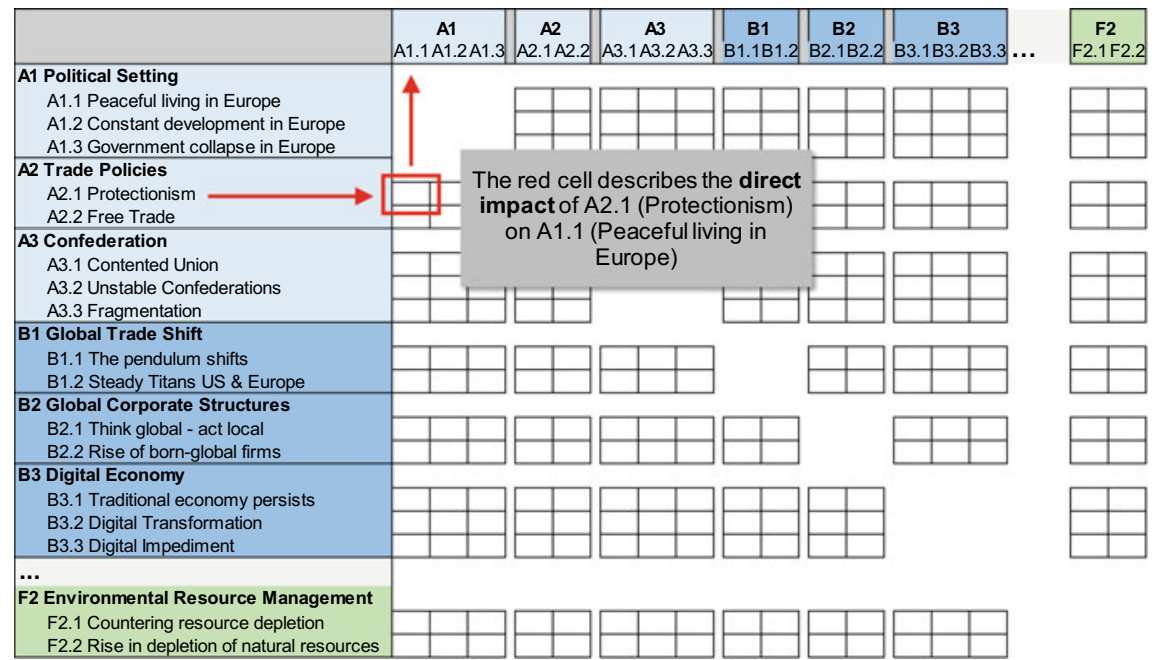

Fig. 2 CIB matrix to support judgements

cross-impact matrix and its impact balances, all consistent clusters of future projections are considered as suitable scenarios (Gausemeier et al. 1988). For this purpose, all possible scenario sets are evaluated according to their consistency and their logical fitness. The general procedure taken within the Gausemeier approach is shown in Fig. 3.

In order to achieve consistent and plausible scenarios, impact scores serve to conduct consistency and plausibility checks in the CIB. They are calculated for each future projection by selecting the rows (future projections) that belong to the analysed projections of one descriptor bundle and then calculating the column sum.

The impact scores of a descriptor define its impact balance. As an example, Fig. 4 shows three descriptors with two future projections each. The figure reflects two scenarios; each scenario includes one future projection of each descriptor. Within Fig. 4, the scenario in each table is highlighted in grey. Scenario 1 is represented by 'Free Trade', 'High Capability' and 'Digital Impediment'. Scenario 2 consists of the future projection 'Free Trade', 'High Capability' and 'Digital Transformation' (instead of 'Digital Impediment'). In Scenario 1, the impact score for 'Free Trade' is calculated by adding the numbers at the vertical intersection with 'High Capability' and 'Digital Impediment', $0+(-1)=-1$. In Scenario 2 though, the impact score for 'Free Trade' results in $0+1=1$ (please refer to encircled numbers within the figure).

In accordance with the CIB consistency principle, the scenario set has to represent the maximum impact score within an impact balance. Hence, for a consistent scenario, the chosen future projections have to achieve the maximum impact score within each descriptor. Within Fig. 4, the future projections of each scenario are highlighted with a black arrow on the top of the impact score ('Free Trade', 'High 


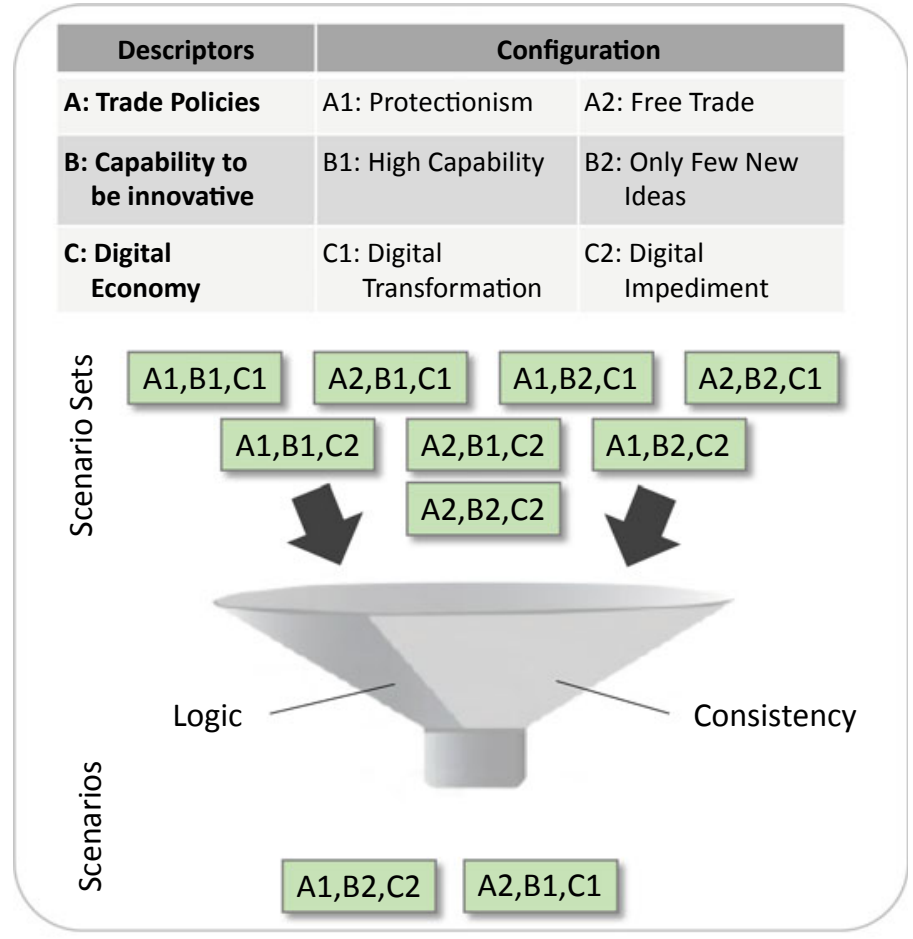

Fig. 3 Achievement of consistent projection bundles

Capability' and 'Digital Impediment' for Scenario 1, 'Free Trade', 'High Capability' and 'Digital Transformation' for Scenario 2). The maximum value of each descriptor is highlighted with a black arrow below the impact score ('Protectionism', 'Only Few New Ideas' and 'Digital Transformation' for Scenario 1, 'Free Trade', 'High Capability' and 'Digital Transformation' for Scenario 2). Once all arrows point to the same projection, the scenario counts as consistent. This is the case in Scenario 2 (lower table in Fig. 4), where all maximum values of the impact scores correspond to the projection within the scenario set. On the contrary, according to CIB, Scenario 1 is considered as inconsistent as none of the scenario assumptions fits to the maximum impact balances.

The CIB offers various evaluation options for determining consistent scenarios. Scenario 2 considered in the example above applies "strong consistency". This option returns only those scenarios in which the scenario assumption corresponds to the highest impact score in any case (Weimer-Jehle 2008). To increase the diversity of the resulting scenarios in order to cover a wider scenario space, it is also possible to loosen the consistency principle and to allow for a certain inconsistency value while retaining the validity and plausibility of this scenario (Weimer-Jehle 2018). 


\begin{tabular}{|c|c|c|c|c|c|}
\hline \multirow{3}{*}{$\begin{array}{l}\text { Cross-Impact-Matrix } \\
\text { "How does development } \\
\text { path i (line) influence } \\
\text { development path j } \\
\text { (column)?" }\end{array}$} & \multicolumn{5}{|c|}{ Scenario 1} \\
\hline & \multicolumn{2}{|c|}{$\begin{array}{c}\text { Trade } \\
\text { Policies }\end{array}$} & $\begin{array}{c}\text { Capability to } \\
\text { be } \\
\text { innovative }\end{array}$ & \multicolumn{2}{|c|}{$\begin{array}{l}\text { Digital } \\
\text { Economy }\end{array}$} \\
\hline & 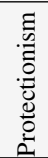 & 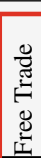 & 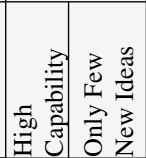 & 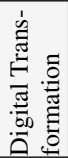 & 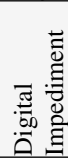 \\
\hline \begin{tabular}{l|l} 
Trade & Protectionism
\end{tabular} & & & -1 & -1 & 1 \\
\hline $\begin{array}{ll}\text { Policies } & \text { Free Trade }\end{array}$ & & & -1 & 2 & -1 \\
\hline \begin{tabular}{l|l} 
Capability & High \\
Capability
\end{tabular} & 0 & 0 & & 2 & -2 \\
\hline \begin{tabular}{c|l} 
to be & Only Few New \\
Innovative & $\begin{array}{l}\text { Ideas } \\
\text { Ies }\end{array}$
\end{tabular} & 0 & 0 & & -2 & 2 \\
\hline \begin{tabular}{l|l|} 
Digital & Digital \\
Transformation
\end{tabular} & -1 & 1 & -1 & & \\
\hline \begin{tabular}{|l|l|} 
Economy & $\begin{array}{l}\text { Digital } \\
\text { Impediment }\end{array}$ \\
\end{tabular} & 0 & -1 & -1 & & \\
\hline Scenario assumptions: & & & 7 & & $\nabla$ \\
\hline Balance: & 0 & -1 & $\overline{0}$ & $\overline{4}$ & -3 \\
\hline
\end{tabular}

The impact score of a development path

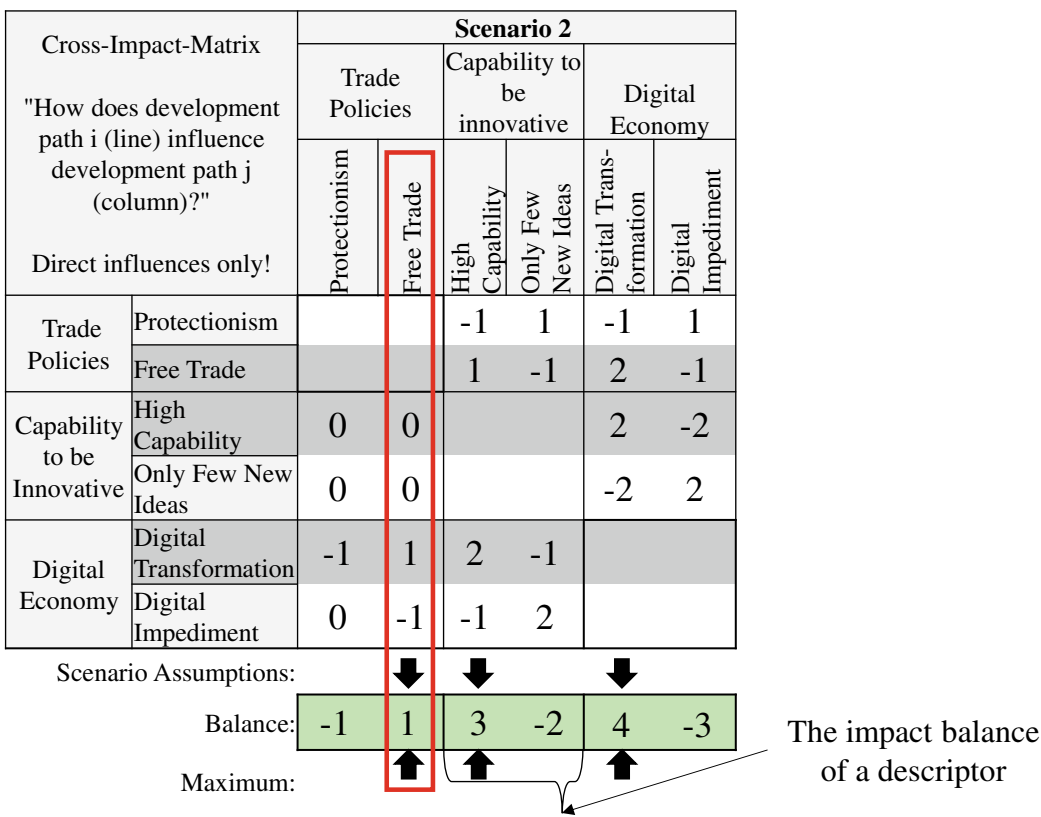

Fig. 4 Example CIB consistency calculation 
Its simple comprehensibility and its potential to work through a complex network of interdependent factors make consistency analysis an attractive compromise between simplicity and analytical depth.

\subsection{Resulting Set of Scenarios}

In the underlying case, around 63 million possible projection bundles had to be evaluated. For the consistency check conducted by the CIB tool, several consistency criteria were defined in order to reduce the range of solutions. This has resulted in twelve consistent scenarios. Two of the resulting scenarios show an overall progressive development. Foremost, a stable political and economic environment characterizes these scenarios (Aspirant and Proceeding). Regressive overall development characterizes two further scenarios represented by a politically and economically unstable situation, as well as lagging legislation and poor environmental conditions (Escapism and Endanger). All other scenarios can be classified in between, they show mixed developments. Figure 5 displays the scenarios and the configuration of the projections.

\subsection{Validation and Selection of the Scenarios}

After the quantitative method of locating consistent scenarios has been carried out, it is necessary to validate the scenarios qualitatively to increase their interpretability and validity. Following the methodology, it is necessary to evaluate the probability of occurrence of a scenario and its impact strength on the decision field. In the underlying case, the evaluation assesses the impact strength of the macro scenario setting on supply chains. The latter evaluates the potential pressure for changes on current supply chain settings.

An expert-workshop is chosen to fulfil this qualitative task. Again, with regard to the topic concerning the creation of future scenarios, it is recommended to select experts with a diverse background and from different industrial sectors. A discussion round between the experts helps to formulate scenario narratives. The results of the evaluation of the scenarios are then transferred into a probability-impact-matrix thus displaying the overall distribution of the scenarios. Figure 6 shows the result for the probability and impact evaluation of the retrieved scenarios.

The outcome of the assessment serves to refine the results of those scenarios which are probable and plausible and necessitate a change to future supply chains. As recommended in the literature, the number of scenarios has to be restricted to allow thorough further analysis with detailed scenario narratives. Bradfield et al. (2005) recommend a scenario set of three to six scenarios using a quantitative approach combined with expert judgements. The final number of selected scenarios is highly dependent on the number of future projections considered and their uncertainties (Amer et al. 2013). 


\begin{tabular}{|c|c|c|c|c|c|c|}
\hline & ASPIRANT & PrOCEEDINg & oFFsET & $\underset{\text { Brink }}{\text { EpOCHAL }}$ & SPIN DOWN & CIRCuiT \\
\hline Political Setting & \multicolumn{2}{|c|}{ Political concord in Europe } & \multicolumn{4}{|c|}{ Constant development in Europe } \\
\hline Trade Policies & \multicolumn{5}{|c|}{ Free Trade } & Protectionism \\
\hline Confederation & \multicolumn{2}{|c|}{ Contended Union } & \multicolumn{2}{|c|}{ Unstable Confederations } & Fragmentation & $\begin{array}{c}\text { Unstable } \\
\text { Confederations }\end{array}$ \\
\hline Global Trade Shift & \multicolumn{2}{|c|}{ Steady Titans US \& Europe } & \multicolumn{4}{|c|}{ The pendulum shifts } \\
\hline $\begin{array}{l}\text { Global Corporate } \\
\text { Structures }\end{array}$ & $\begin{array}{l}\text { Rise of born- } \\
\text { global firms }\end{array}$ & \multicolumn{2}{|c|}{ Think global, act local } & $\begin{array}{l}\text { Rise of born- } \\
\text { global firms }\end{array}$ & \multicolumn{2}{|c|}{ Think global, act local } \\
\hline Digital Economy & \multicolumn{2}{|c|}{ Platform economy } & $\begin{array}{c}\text { Pure traditional } \\
\text { economy }\end{array}$ & $\begin{array}{l}\text { Traditional } \\
\text { economy } \\
\text { persists }\end{array}$ & \multicolumn{2}{|c|}{ Pure traditional economy } \\
\hline Financial Innovations & $\begin{array}{l}\text { Big } 5 \text { are the } \\
\text { banks of the } \\
\text { future }\end{array}$ & $\begin{array}{l}\text { Bank and } \\
\text { Fintech } \\
\text { collaboration } \\
\end{array}$ & \multicolumn{2}{|c|}{ Big 5 are the banks of the future } & $\begin{array}{l}\text { A world } \\
\text { without banks }\end{array}$ & $\begin{array}{l}\text { Big } 5 \text { are the } \\
\text { banks of the } \\
\text { future }\end{array}$ \\
\hline Demographic Change & \multicolumn{3}{|c|}{ Awareness of inequalities and wealth redistribution } & \begin{tabular}{|c|} 
Ageing pop. \& \\
acceleration of \\
disparities
\end{tabular} & $\begin{array}{l}\text { Awareness of } \\
\text { ineq. \& wealth } \\
\text { redistrib. }\end{array}$ & \begin{tabular}{|c|} 
Ageing pop. \& \\
acceleration of \\
disparities
\end{tabular} \\
\hline Urban Living & Smart regions & \multicolumn{4}{|c|}{ Smart cities } & Smart regions \\
\hline Consumption Patterns & $\begin{array}{l}\text { Consumption } \\
\text { awareness }\end{array}$ & DIY Society & \multicolumn{2}{|c|}{ Much and cheap } & \multicolumn{2}{|c|}{ DIY Society } \\
\hline Customer Orientation & $\begin{array}{l}\text { Collectivism - } \\
\text { Focus on the } \\
\text { crowd }\end{array}$ & $\begin{array}{l}\text { Individualism - } \\
\text { Focus on } \\
\text { variety }\end{array}$ & \multicolumn{2}{|c|}{ Collectivism - Focus on the crowd } & \multicolumn{2}{|c|}{ Individualism - Focus on variety } \\
\hline $\begin{array}{l}\text { Knowledge-based } \\
\text { Economy }\end{array}$ & \multicolumn{3}{|c|}{ Investments equalise the labour market } & \begin{tabular}{|c|} 
Rapid changes \\
cause \\
unemployment \\
\end{tabular} & $\begin{array}{l}\text { Investments } \\
\text { equalise the } \\
\text { labour market }\end{array}$ & $\begin{array}{c}\text { Rapid changes } \\
\text { cause } \\
\text { unemployment }\end{array}$ \\
\hline Digital Transformation & \multicolumn{2}{|c|}{$\begin{array}{l}\text { Rapid advancement of } \\
\text { digitalisation }\end{array}$} & \multicolumn{4}{|c|}{ Obstacles restrain digital transformation } \\
\hline Autonomous Systems & \multicolumn{2}{|c|}{$\begin{array}{l}\text { Dynamic development of } \\
\text { autonomous technologies }\end{array}$} & $\begin{array}{l}\text { Innate rel. to } \\
\text { accept aut. } \\
\text { tech. } \\
\end{array}$ & \begin{tabular}{|c|}
$\begin{array}{c}\text { Dynamic dev. of } \\
\text { autonomous } \\
\text { tech. }\end{array}$ \\
\end{tabular} & \multicolumn{2}{|c|}{$\begin{array}{l}\text { Innate reluctance to accept } \\
\text { autonomous technologies }\end{array}$} \\
\hline $\begin{array}{l}\text { Altern. energy generation; } \\
\text { storage \& usage }\end{array}$ & \multicolumn{2}{|c|}{$\begin{array}{c}\text { Established Electrification } \\
\text { Technologies and Green Systems }\end{array}$} & \multicolumn{3}{|c|}{$\begin{array}{l}\text { Ongoing electrification and alternative energy } \\
\text { endeavours }\end{array}$} & $\begin{array}{l}\text { Est. Elec. Tech. } \\
\text { \& Green Sys. }\end{array}$ \\
\hline $\begin{array}{l}\text { Decentralised connection } \\
\text { of information and } \\
\text { physical devices }\end{array}$ & $\begin{array}{l}\text { Dominance of } \\
\text { Global Players }\end{array}$ & $\begin{array}{c}\text { Start-ups and } \\
\text { SMEs take up } \\
\text { business } \\
\end{array}$ & Dominance of & Global Players & $\begin{array}{c}\text { Start-ups and } \\
\text { SMEs take up } \\
\text { business } \\
\end{array}$ & $\begin{array}{l}\text { Dominance of } \\
\text { Global Players }\end{array}$ \\
\hline $\begin{array}{l}\text { Disruptive Production } \\
\text { Technologies }\end{array}$ & \multicolumn{2}{|c|}{$\begin{array}{l}\text { Continuous exploitation of } \\
\text { disruptive technologies }\end{array}$} & \multicolumn{4}{|c|}{ Coexistence of conventional and disruptive technologies } \\
\hline $\begin{array}{l}\text { Consumer Protection } \\
\text { Laws }\end{array}$ & \multicolumn{2}{|c|}{$\begin{array}{l}\text { Promotion of laws and full } \\
\text { product transparency }\end{array}$} & \multicolumn{4}{|c|}{ Legislation is lagging behind dynamic market development } \\
\hline Intellectual Property Laws & \multicolumn{2}{|c|}{$\begin{array}{l}\text { Full security for inventors and } \\
\text { data providers }\end{array}$} & \multicolumn{4}{|c|}{ Low confidentiality for data and market participants } \\
\hline $\begin{array}{l}\text { Social and Environmental } \\
\text { Regulations }\end{array}$ & \multicolumn{2}{|c|}{$\begin{array}{l}\text { Comprehensive regulatory } \\
\text { framework }\end{array}$} & \multicolumn{4}{|c|}{ Heterogeneous regulations } \\
\hline Climate Change & \multicolumn{2}{|c|}{ Our environmenti s recovering } & Our en & avironment on the & brink & $\begin{array}{c}\text { Our } \\
\text { environmentis } \\
\text { recovering }\end{array}$ \\
\hline $\begin{array}{l}\text { Environmental Resource } \\
\text { Management }\end{array}$ & Countering res & urce depletion & Rise in de & pletion of natural & resources & $\begin{array}{l}\text { Countering } \\
\text { resource } \\
\text { depletion }\end{array}$ \\
\hline
\end{tabular}

Fig. 5 Overview of the twelve selected scenarios

As displayed in Fig. 6, the assessment resulted in six scenarios that force a strong to medium change on the supply chain (impact factor $>3$ ) and have a rather high probability $(>35 \%)$. 


\begin{tabular}{|c|c|c|c|c|c|c|}
\hline & OUTsET & DiThER & Almost BLACK & UNEasE & EScAPiSm & ENDANGEr \\
\hline Political Setting & \multicolumn{4}{|c|}{ Constant development in Europe } & \multicolumn{2}{|c|}{ Governmental collapse in Europe } \\
\hline Trade Policies & \multicolumn{4}{|c|}{ Protectionism } & Free Trade & Protectionism \\
\hline Confederation & \multicolumn{6}{|c|}{ Fragmentation } \\
\hline Global Trade Shift & \multicolumn{6}{|c|}{ The pendulum shifts } \\
\hline $\begin{array}{l}\text { Global Corporate } \\
\text { Structures }\end{array}$ & \multicolumn{6}{|c|}{ Think global, act local } \\
\hline Digital Economy & $\begin{array}{c}\text { Pure traditional } \\
\text { economy }\end{array}$ & \multicolumn{2}{|c|}{ Platform economy } & $\begin{array}{c}\text { Traditional } \\
\text { economy } \\
\text { persists }\end{array}$ & $\begin{array}{l}\text { Platform } \\
\text { economy }\end{array}$ & $\begin{array}{c}\text { Traditional } \\
\text { economy } \\
\text { persists } \\
\end{array}$ \\
\hline Financial Innovations & $\begin{array}{l}\text { Big } 5 \text { are the } \\
\text { banks of the } \\
\text { future }\end{array}$ & $\begin{array}{l}\text { Bank and } \\
\text { Fintech } \\
\text { collaboration }\end{array}$ & $\begin{array}{l}\text { Big } 5 \text { are the } \\
\text { banks of the } \\
\text { future }\end{array}$ & $\begin{array}{l}\text { Bank and } \\
\text { Fintech } \\
\text { collaboration }\end{array}$ & A world wit & hout banks \\
\hline Demographic Change & \begin{tabular}{|c|} 
Awareness of \\
ineq. $\&$ wealth \\
redistrib.
\end{tabular} & \multicolumn{5}{|c|}{ Ageing population and acceleration of disparities } \\
\hline Urban Living & \multicolumn{6}{|c|}{ Smart cities } \\
\hline Consumption Patterns & $\begin{array}{c}\text { Consumption } \\
\text { awareness }\end{array}$ & \multicolumn{4}{|c|}{ DIY Society } & $\begin{array}{l}\text { Much and } \\
\text { cheap }\end{array}$ \\
\hline Customer Orientation & \multicolumn{5}{|c|}{ Individualism - Focus on variety } & $\begin{array}{l}\text { Collectivism - } \\
\text { Focus on the } \\
\text { crowd }\end{array}$ \\
\hline $\begin{array}{l}\text { Knowledge-based } \\
\text { Economy }\end{array}$ & $\begin{array}{l}\text { Investments } \\
\text { equalise the } \\
\text { labour market }\end{array}$ & \multicolumn{3}{|c|}{ Rapid changes cause unemployment } & \begin{tabular}{|c|} 
Investments \\
equalise the \\
labour market
\end{tabular} & \begin{tabular}{|c}
$\begin{array}{c}\text { Rapid changes } \\
\text { cause } \\
\text { unemployment }\end{array}$ \\
\end{tabular} \\
\hline Digital Transformation & $\begin{array}{l}\text { Digital } \\
\text { Stagnation }\end{array}$ & \multicolumn{5}{|c|}{ Obstacles restrain digital transformation } \\
\hline Autonomous Systems & $\begin{array}{l}\text { Innate rel. to } \\
\text { accept aut. } \\
\text { tech. }\end{array}$ & \multicolumn{2}{|c|}{$\begin{array}{l}\text { Dynamic development of } \\
\text { autonomous technologies }\end{array}$} & $\begin{array}{l}\text { Innate rel. to } \\
\text { accept aut. } \\
\text { tech. } \\
\end{array}$ & \multicolumn{2}{|c|}{$\begin{array}{l}\text { Dynamic development of } \\
\text { autonomous technologies }\end{array}$} \\
\hline $\begin{array}{l}\text { Altern. energy generation; } \\
\text { storage \& usage }\end{array}$ & \multicolumn{2}{|c|}{$\begin{array}{c}\text { Established Electrification } \\
\text { Technologies and Green Systems }\end{array}$} & \multicolumn{4}{|c|}{ Ongoing electrification and alternative energy endeavours } \\
\hline $\begin{array}{l}\text { Decentralised connection } \\
\text { of information and } \\
\text { physical devices }\end{array}$ & $\begin{array}{l}\text { Dominance of } \\
\text { Global Players }\end{array}$ & $\begin{array}{l}\text { Start-ups and } \\
\text { SMEs take up } \\
\text { business }\end{array}$ & $\begin{array}{l}\text { Dominance of } \\
\text { Global Players }\end{array}$ & $\begin{array}{r}\text { Start-ups and } \\
\text { bus }\end{array}$ & $\begin{array}{l}\text { SMEs take up } \\
\text { ness }\end{array}$ & $\begin{array}{l}\text { Dominance of } \\
\text { Global Players }\end{array}$ \\
\hline $\begin{array}{l}\text { Disruptive Production } \\
\text { Technologies }\end{array}$ & \begin{tabular}{|c|} 
Coexistence of \\
conv. and \\
disruptive tech. \\
\end{tabular} & \multicolumn{2}{|c|}{$\begin{array}{c}\text { Continuous exploitation of } \\
\text { disruptive technologies }\end{array}$} & $\begin{array}{c}\text { Coexistence of } \\
\text { conv. and } \\
\text { disruptive tech. }\end{array}$ & \begin{tabular}{|c|} 
Continuous \\
exploitation of \\
disruptive tech. \\
\end{tabular} & $\begin{array}{c}\begin{array}{c}\text { Coexistence of } \\
\text { conv. and } \\
\text { disruptive tech. }\end{array} \\
\end{array}$ \\
\hline $\begin{array}{l}\text { Consumer Protection } \\
\text { Laws }\end{array}$ & \multicolumn{6}{|c|}{ Legislation is lagging behind dynamic market development } \\
\hline Intellectual Property Laws & \multicolumn{6}{|c|}{ Low confidentiality for data and market participants } \\
\hline $\begin{array}{l}\text { Social and Environmental } \\
\text { Regulations }\end{array}$ & \multicolumn{6}{|c|}{ Heterogeneous regulations } \\
\hline Climate Change & $\begin{array}{c}\text { Our } \\
\text { environment } \\
\text { on the brink }\end{array}$ & \begin{tabular}{|c|} 
Our \\
environmentis \\
recovering
\end{tabular} & \multicolumn{4}{|c|}{ Our environment on the brink } \\
\hline $\begin{array}{l}\text { Environmental Resource } \\
\text { Management }\end{array}$ & $\begin{array}{c}\text { Rise in } \\
\text { depletion of } \\
\text { natural res. }\end{array}$ & \begin{tabular}{|c|} 
Countering \\
resource \\
depletion
\end{tabular} & \multicolumn{4}{|c|}{ Rise in depletion of natural resources } \\
\hline
\end{tabular}

Fig. 5 (continued) 


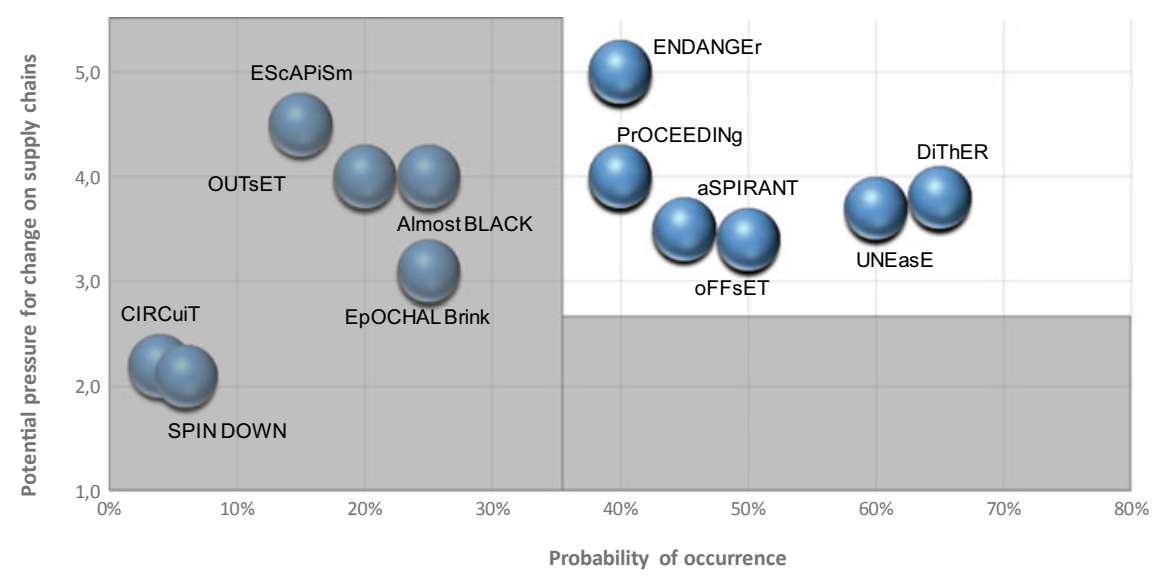

Fig. 6 Overview of the assessment of the scenarios and scenario selection

\section{Conclusion}

Various methodologies can be applied to create future developments. This chapter describes a methodology that integrates quantitative and qualitative approaches. The applied methodology differs from a pure prognosis or forecast. Instead, it provides several possible future scenarios on how the macro surroundings for supply chains might look in a time horizon until 2030. This approach has the advantage that deduced policy decisions or company strategies consider possible changes in future conditions. This approach results in the selection of six validated scenarios that have a great impact on the design of future supply chains. From a managerial perspective, the results enable early preparations to be carried out for various potential development paths until 2030. Both countries and companies can benefit from this: since alternative plans are available on shorter notice, necessary measures to strengthen competitiveness can be initiated much earlier and in a more targeted manner.

Acknowledgements The execution and application of this scenario building technique have been made possible with the support of a group of experts who participated in the EU project NextNet. We also extend our sincere thanks to our project partners for their fruitful cooperation and for developing the scenarios. Special thanks for their support go to Ana Cristina Barros (INESC-TEC), Rosanna Fornasiero (STIIMA-CNR), Dimitra Kalaitzi (Aston), Victoria Muerza (ZLC).

\section{References}

Agriculture and Agri-Food Canada (2010) Global consumer trends: individualism. http://publicati ons.gc.ca/collections/collection_2013/aac-aafc/A74-2-2010-1-eng.pdf. Accessed 28 Mar 2018 Amer M, Daim TU, Jetter A (2013) A review of scenario planning. Futures 46:23-40 
Barros AC, Senna P, Marchiori I, Kalaitzi D, and Balech S (2020) Scenario-driven supply chain charaterization using a multi-dimensional approach. In: Fornasiero et al (ed) Next generation supply chains: a roadmap for research and innovation. Springer

Bingley M, Esteban Lauzán JF, Hall J, Jagdale G, Pfeil M, Smith M, Pinheiro F, Tardieu H (2016) Journey 2020—digital shockwaves in business

Boerjeson L, Hoejer M, Dreborg K-H, Ekvall T, Finnveden G (2006) Scenario types and techniques: towards a user's guide. Future 38:723-739

Bouee C-E, Schaible S (2015) The digital transformation of industry: how important is it? Who are the winners? What must be done now? Muinch

Bradfield R, Wright G, Burt G, Cairns G, van der Heijden K (2005) The origins and evolution of scenario techniques in long range business planning. Futures 37: 795-812

Brynjolfsson E, Kahin B (2000) Understanding the digital economy: data, tools, and research

Ceniga P, Sukalovaba V (2015) Future of logistics management in the process of globalization. Proc Econ Fin 26:160-166

Coleman S, Göb R, Manco G, Pievatolo A, Tort-Martorell X, Reis MS (2016) How Can SMEs benefit from big data? Challenges and a path forward. Qual Reliabil Eng Int 32(6):2151-2164

Daus D, Barros A, Kalaitzi D, Muerza V, Marchiori I (2018) Alternative development paths for supply chains in 2030: proceedings of the hamburg international conference of logistics 12 (HICL)

de Kluyver CA (2010) Fundamentals of global strategy: a business model approach. Business Expert Press, Harvard, New York, NY

Deloitte (2015) Making it personal—one in three consumers wants personalised products. https:// www2.deloitte.com/uk/en/pages/press-releases/articles/one-in-three-consumers-wants-person alised-products.html. Accessed 31 Oct 2017

DHL (2012) Delivering tomorrow: logistics 2050 a scenario study

DHL Customer Solutions and Innovation (2016) Robotics in logistics: a DPDHL perspective on implications and use cases for the logistics industry

Enserink B, Kwakkel JH, Veenman S (2013) Coping with uncertainty in climate policy making: (Mis)understanding scenario studies. Futures 53:1-12

European Commission (2016) Clean energy for all Europeans

European Commission (2018) A European strategy for plastic in a circular economy

EUROPOL (2017) European union terrorism situation and trend report 2017. https://www.europol. europa.eu/newsroom/news/2017-eu-terrorism-report-142-failed-foiled-and-completed-attacks1002-arrests-and-142-victims-died. Accessed 03 Jan 2017

Eurostat (2016) Household consumption by purpose. http://ec.europa.eu/eurostat/statistics-explai ned/index.php/Household_consumption_by_purpose. Accessed 06 Jan 2018

Fintechnews Singapore (2016) The future of finance: a world without banks. http://fintechnews.sg/ 5530/fintech/the-future-of-finance-a-world-without-banks/. Accessed 28 Mar 2018

Frank B, Enkawa T, Schvaneveldt SJ (2015) The role of individualism versus collectivism in the formation of repurchase intent: a cross-industry comparison of the effects of cultural and personal values. J Econ Psychol 51

Gausemeier, Plass (2014) Zukunftsorientierte Unternehmensgestaltung - Strategien, Geschäftsprozesse und IT-Systeme für die Produktion von morgen, 2nd edn. Carl Hanser Fachbuchverlag, München

Gausemeier J, Fink A, Schlake O (1995) Szenario-Management: Planen und Führen mit Szenarien. Carl Hanser Verlag, München Wien

Gausemeier J, Fink A, Schlake O (1988) Scenario management: an approach to develop future potentials. Technol Forecasting Social Change 59:111-130

Gordon TJ (1994) Trend impact analysis. Futures Research Methodology

Governance and Accountability Institute (2016) FLASH REPORT: 81\% of S\&P 500 Companies published sustainability reports in 2015. https://www.ga-institute.com/press-releases/article/ flash-report-82-of-the-sp-500-companies-published-corporate-sustainability-reports-in-2016.

html. Accessed 12 Dec 2017 
Howell S, Rezgui Y, Hippolyte J-L, Jayan B, Li H (2017) Towards the next generation of smart grids: semantic and holonic multi-agent management of distributed energy resources. Renew Sustain Energy Rev 77:193-214

Jiang R, Kleer R, Piller FT (2017). Predicting the future of additive manufacturing: a Delphi study on economic and societal implications of 3D printing for 2030. Technol Forecasting Soc Change 117:84-97

Kalaitzi D, Matopoulos A, Fornasiero R, Sardesai S, Barros AC, Balech S, Muerza V (2020) Megatrends and trends shaping supply chain innovation. In: Fornasiero et al. (ed) Next generation supply chains: a roadmap for research and innovation. Springer

Karathodorou A (2018) Smart Ledger (aka blockchain) Technology. http://www.longfinance.net/ programmes/distributed-futures-menu/df-mdls.html. Accessed 28 Feb 2018

Kharas H (2017) The unprecedented expansion of the global middle class: an update. Washington

Krys C, Fuest K (2016) Trend 3: scarcity of resources

Krys C, Fuest K (2017) Megatrend 1 demographic dynamics, roland berger trend compendium 2030

Laudon KC, Traver CG (2014) E-commerce: business. technology. society, 10th edn. Pearson Education, New Jersey

Lorenz M, Rüßmann M, Heidemann A (2016) Time to accelerate in the race toward industry 4.0

McKinsey (2010) A portfolio of power-trains for Europe: a fact-based analysis- the role of battery electric vehicles, plug-in hybrids and fuel cell electric vehicles

Meinert S (2014) Field Manuel: scenario building

Menon R (2014) Global or Glocal: the future course for strategy? Glob J Fin Manage 6(5):427-432

Mittal N, Sharma S, Verma A, FrankD (2017) Enterprise data sovereignty: if you love your data, set it free

Omohundro S (2014) Autonomous technology and the greater human good. J Exp Theor Artif Intell 26(3):303-315

PwC-Price Waterhouse Coopers (2011) Pharma 2020: supplying the future which path will you take?

PwC-Price Waterhouse Coopers (2015) The world in 2050 will the shift in global economic power continue?

PwC_-Price Waterhouse Coopers (2016) Datenaustausch als wesentlicher Bestandteil der Digitalisierung

PwC-Price Waterhouse Coopers (2017a) FinTech trends report: a deep dive into what's driving the FinTech revolution in India

PwC-Price Waterhouse Coopers (2017b) How the UK has embraced the sharing economy hub. https://www.pwc.co.uk/issues/megatrends/collisions/sharingeconomy/outlook-for-the-sha ring-economy-in-the-uk-2016.html. Accessed 06 Jan 2018

Rhodes A (2017) Uber: which countries have banned the controversial taxi app

Sardesai S, Stute M, Fornasiero R, Kalaitzi D, Barros AC, Multu C, Muerza V (2020) Future scenario settings for supply chains. In: Fornasiero et al (ed) Next generation supply chains: a roadmap for research and innovation. Springer

Schwartz HG, Meyer M, Burbank CJ, Kuby M, Oster C, Posey J, Russo EJ, Rypinski A (2014) Ch. 5: Transportation. Climate change impacts in the United States: The Third National Climate Assessment

Shah A, Roongta P, Jain C, Kaushik V, Awadhiya A (2016) Digital payments 2020: the making of a $\$ 500$ Billion ecosystem in India

Stokes B (2016) Euroskepticism beyond Brexit: significant opposition in key European countries to an ever closer EU. http://www.pewglobal.org/2016/06/07/euroskepticism-beyond-brexit/. Accessed 07 Feb 2018

Stiftung B (2017a) Rule of law in poland and Hungary: "our fundamental values are under attack". https://www.bertelsmann-stiftung.de/en/topics/aktuelle-meldungen/2017/september/pol and-and-hungary-our-fundamental-values-are-under-attack/. Accessed 07 Feb 2018 
Stiftung B (2017b) Securing a good neighbourhood in the south and east. https://www.bertel smann-stiftung.de/en/our-projects/strengthening-and-connecting-europe/news/securing-a-goodneighbourhood-in-the-south-and-east/. Accessed 07 Feb 2018

Stiftung B (2018) Europeans see the EU as a protective umbrella in the era of globalization. https://www.bertelsmann-stiftung.de/en/topics/aktuelle-meldungen/2018/januar/europe ans-see-the-eu-as-a-protective-umbrella-in-the-era-of-globalization/. Accessed 07 Feb 2018

Weerawardena J, Mort GS, Liesch PW, Knight G (2007) Conceptualizing accelerated internationalization in the born global firm: a dynamic capabilities perspective. J World Bus 42(3):294-306

Weimer-Jehle W (2006) Cross-impact balances: a system-theoretical approach to cross-impact analysis. Technol Forecast Soc Chang 73(4):334-361

Weimer-Jehle W (2008) Cross-impact balances: Applying pair interactions systems and multi-value Kauffman nets to multidisciplinary systems analysis. Phys A Stat Mech App 387(14):3689-3700

Weimer-Jehle W (2009) Szenarienentwicklung mit der Cross-Impact Bilanzanalyse. Stuttgart

Weimer-Jehle W (2018) ScenarioWizard 4.3: Programm zur qualitativen System- und Szenarioanalyse mit der Cross-Impact Bilanzanalyse (CIB). http://www.cross-impact.de/Ressourcen/Sce narioWizardManual_dt.pdf. Accessed 29 May 2018

WHO (2004) Changement climatique et santé humaine: Risques et mesures à prendre résumé. Organisation mondiale de la santé, Genève

Wilkinson A, Eidinow E (2008) Evolving practices in environmental scenarios: a new scenario typology. Environ Res Lett 3

Wolf M, McQuitty S (2011) Understanding the do-it-yourself consumer: DIY motivations and outcomes. AMS Rev 1:154-170

World Economic Forum (2016a) Digital transformation of industries: digital enterprise

World Economic Forum (2016b) The world's free trade areas-and all you need to know about them. USA

WTO (2017) Trade recovery expected in 2017 and 2018, amid policy uncertainty. https://www.wto. org/english/news_e/pres17_e/pr791_e.htm. Accessed 06 Jan 2018

Zelt T, Ibel J, Tuncer F (2017) The rise of the smart city, Cities around the world are embracing the digital revolution. But how well are they really doing? Muinch

ZIRIUS (2020) Cross-impact balance analysis. http://www.cross-impact.de/english/CIB_e.htm. Accessed 02 July 2020

Open Access This chapter is licensed under the terms of the Creative Commons Attribution 4.0 International License (http://creativecommons.org/licenses/by/4.0/), which permits use, sharing, adaptation, distribution and reproduction in any medium or format, as long as you give appropriate credit to the original author(s) and the source, provide a link to the Creative Commons license and indicate if changes were made.

The images or other third party material in this chapter are included in the chapter's Creative Commons license, unless indicated otherwise in a credit line to the material. If material is not included in the chapter's Creative Commons license and your intended use is not permitted by statutory regulation or exceeds the permitted use, you will need to obtain permission directly from the copyright holder.

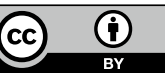

